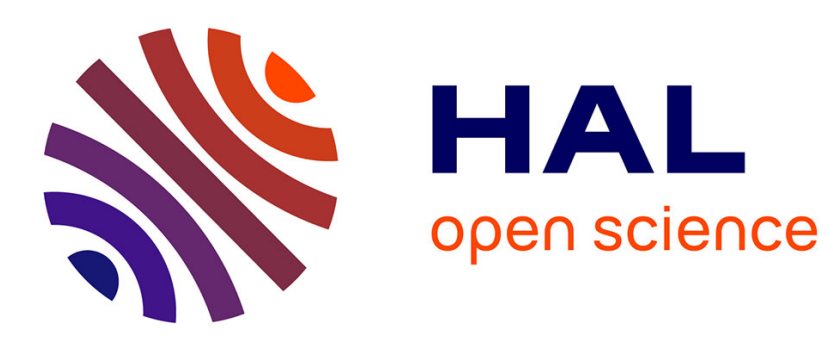

\title{
The circulation of euro coins as markers of European mobility in France
}

\author{
France Guérin-Pace, Marion Le Texier
}

\section{To cite this version:}

France Guérin-Pace, Marion Le Texier. The circulation of euro coins as markers of European mobility in France. Revue Europeenne des Sciences Sociales, 2016, 54-1, pp.129-152. 10.4000/ress.3484 . hal-01651855

\section{HAL Id: hal-01651855 \\ https://hal.science/hal-01651855}

Submitted on 30 Nov 2017

HAL is a multi-disciplinary open access archive for the deposit and dissemination of scientific research documents, whether they are published or not. The documents may come from teaching and research institutions in France or abroad, or from public or private research centers.
L'archive ouverte pluridisciplinaire HAL, est destinée au dépôt et à la diffusion de documents scientifiques de niveau recherche, publiés ou non, émanant des établissements d'enseignement et de recherche français ou étrangers, des laboratoires publics ou privés. 
The Circulation of euro coins as Markers of European Mobility in France La circulation des pièces euro comme trace de la mobilité européenne en France.

Authors: France Guérin-Pace (INED, Paris, France) and Marion Le Texier (European University Institute, Florence, Italy)

\section{Emails:}

France Guérin-Pace (guerin@ined.fr)

Marion Le Texier (marion.le-texier@univ-rouen.fr) 
Abstract: This study examines the social and territorial structure of the relations between Eurozone countries and residents that we grasp by studying the diffusion of foreign Euro coins (2002-2011). As a Euro coin is conveyed across space by persons, it offers a good representation of both social and spatial networks, as well as it allows the study of both social and territorial inequalities with regards to international accessibility. We use a series of individual-level representative surveys describing the content of the money bag of an amount of 21,669 respondents and analyse internationalisation differences using logistic regressions. The results show that students and executives are the social categories that are the most connected to neighbouring peoples and which are therefore potential vectors of European identity. They also demonstrate strong spatial and territorial variations of the openness of places and people to the rest of Europe - everything else being equal.

Keywords: euro, markers, mobility, international contacts, Europe, logistic regression.

Résumé: Cet article s'intéresse à la structure des relations sociales et territoriales qui se tissent en Europe à partir d'une source originale : les pièces euro. Depuis leur mise en circulation au 1er janvier 2002, les pièces euro traversent les frontières au rythme des mobilités et des achats que réalisent les individus. L'évolution de leur répartition constitue ainsi un marqueur indirect de la mise en réseau des territoires et des hommes dans cette partie du monde. Plus précisément, nous étudions, par le biais de régressions logistiques, la prévalence de pièces étrangères observées dans le porte-monnaie de 21,669 enquêtés en France au cours des dix dernières années (2002-2011). Si les étudiants et les cadres constituent les vecteurs les plus importants de cette mise en relation européenne à l'échelle nationale, cet avantage est plus ou moins marqué selon les lieux de résidence : espaces transfrontaliers, métropoles spécialisées, destinations touristiques, etc.

Mots-clés: euro, Europe, mobilité, relations internationales, régression logistique, trace.

\section{Introduction}

For nearly a century now, historians have used currency circulation as an indicator of human contacts in time and space. More broadly, the circulation of people and goods in Europe has been the focus of extensive theoretical work in the social sciences (Hudson, 2004). One of the main obstacles for researchers is the difficulty of collecting data on mobility at European level, hindering their attempts to outline a geography of international mobility on the continent. The data at our disposal is mainly based on information segmented by means of transport and by the intra-European travellers involved, with mobility surveys regularly carried out with students, businessmen, tourists and commuters.

When the euro was brought into circulation in 2002, French geographers hypothesised that a spatio-temporal analysis of the distribution of coins minted by each country could 
serve as a relevant marker for individual mobility across Europe. Carried and used by Eurozone residents in their everyday transactions, the single currency lends physical form of contacts between European regions. Spatial structures of varying clarity emerge from the picture of individual social interactions constituted by the mingling of coins. Those structures should reflect the different capacities of territories and social groups to make contact with each other within Europe.

Between March 2002 and December 2011, 16 studies were carried out at regular intervals in France ${ }^{1}$ (Grasland et al., 2002), with over 22,000 purses "surveyed" and 300,000 coins observed and inventoried according to their face value and country of issue (Table 1).

The results of the initial surveys enabled researchers to measure the gradual increase in the mix of euro coins circulating in France according to their geographical origin. Several factors explaining variations in the presence of foreign coins on French territory were highlighted initially (Grasland and Guérin-Pace, 2004). Mechanical effects (the number and value of the coins in a purse) were distinguished from temporal effects (the period of time since the euro was brought into circulation) and the commonplace effects of spatial interaction such as proximity to the border of a euro-zone country or the population size of neighbouring countries (Berroir et al., 2005). The impacts of the individual characteristics of the coin carriers - age, profession, socio-professional category, place of residence - on the presence of foreign coins are more difficult to identify, as low-mobility individuals can come into contact with numerous foreign coins simply by living near an airport. A comprehensive approach embracing both the spatial interaction and socioterritorial effects is still missing.

In this article we propose to analyse the information provided by the "markers" of international mobility left by coins at a given time in a given place, the aim being to distinguish the commonplace from the specific in the circulation of coins. As such, we examine the circulation of euro coins as an indicator of territorialized social interactions. We start by overviewing the data compiled by the Euro Spatial Diffusion Observatory (ESDO) surveys. We then go on to discuss the uneven distribution of foreign euro coins in terms of face value and the varying capacities of individuals to come into contact with foreign coins in line with their socio-demographic characteristics. Lastly, we seek to identify the reasons behind the presence of foreign euro coins in France, which depends on the territories in question.

\section{Observing the diffusion of euro coins in France through a quantitative survey}

1 The surveys were carried out as part of the Euro coins Spatial Diffusion Observatory (ESDO) founded by Claude Grasland and France Guérin-Pace in 2002. The surveys were financed by the French national institute of demographic studies (INED), the French national research institute (CNRS), the French Treasury Department and the Ministry of Tourism. They were carried out by the Lavialle institute (ISL) as part of omnibus surveys with a representative sample of the French population, each one administered to between 1,000 and 2,000 people. 
Collecting information on this complex subject was a challenge for researchers from a range of fields interested in the major European event. Beyond its symbolic aspect, the arrival of the euro constituted a newness for physicists, who finally had before them an experience whose initial conditions they controlled, and for geographers and demographers, the focus of this paper. Obviously, the objectives differed considerably from one discipline to another. For physicists and for mathematicians, for instance, the main aim was to estimate the time it would take to achieve a perfect mix of the coins, namely a state of balance whereby in each country the share of coins with a given origin would be stable (Bergman et al., 2002; Stoyan, 2002). To that end, researchers used Markov models with parameters describing the size of the population and the distance between countries, without taking account of the internal geographical diversity of the countries and the resulting territorial effects. For the sake of simplicity, these studies were based on the collection of web-based information, with the creation of ad hoc sites on which web users were encouraged to regularly detail the content of their purses, i.e. the value and origin of the coins therein. Despite the biases inherent to this collection method, these data made it possible to calibrate the forecasting models developed by physicists (Stoyan, 2002; Seitz et al., 2009; Seitz et al., 2012).

For researchers in the field of social sciences, the aim was more to estimate - in absence of data - the circulation of people across Europe. When the euro was brought into circulation in January 2002, all the coins were theoretically located in the country in which they were minted. The issuing country of a euro coin thus represents the first link in a chain of movements and exchanges. The presence of a foreign euro coin in France then indicates that it has crossed one or more borders, depending on its geographical origin, transported in line with the movements of one or more individuals.

Using the complex object of currency to reveal the spatial mobility of Europeans on French territory hinged on the availability of representative data at the most exact territorial level possible. The protocol used in each of the surveys carried out by ESDO ensured that the sample was representative at $Z_{E A T}^{2}$ level with a sample of around 2,000 people for each survey (Box 1).

The data collected by the 15 surveys between June 2002 and December 2011 enabled researchers to analyse nearly 300,000 coins in over 21,000 purses. Over the course of the decade, the share of foreign coins observed in France rose by a factor of six, from $6 \%$ in June 2002 to $34 \%$ in December 2011 (Table 1).

\section{The complex relationships between the circulation of coins and the movement of}

$2 \quad$ Zones d'Etudes et d'Aménagement du Territoire (Research and National Development Zones, or ZEATs) are administrative areas in France created by the French National Institute of Statistics and Economics Studies (INSEE). They are equivalent to the first level of Europe's Nomenclature of Units for Territorial Statistics, NUTS 1. These areas were modified slightly in the ESDO surveys. The Parisian Basin was split into east and west areas and only the regions of Metropolitan France were taken into consideration. 


\section{people}

\subsection{Currency sources in mobility studies}

Over the last ten years, US physicists have analysed the circulation of one-dollar notes across the United States with a view to furthering understanding on the diffusion of other phenomena, such as epidemics (Brockmann and Hufnagel, 2007; Brockmann and Theis, 2008.). They have notably succeeded in establishing a link between the regularity of the spatio-temporal reach of the movement of the notes and a mathematical law known as Lévy flights ${ }^{3}$.

The introduction of the euro stirred considerable enthusiasm on the part of European researchers in a range of scientific fields. Some researchers have focused on the process in which foreign coins have spread and mixed in the euro zone (Le Texier and Caruso, 2016; Stoyan, 2002; Seitz et al., 2009; Seitz et al., 2012), while others have studied the relationships between the carriers, their territories and the circulation of the coins (Berroir et al., 2005; Nuno et al., 2005; Grasland, 2009; Sohn, 2009).

The aims and approaches of these studies vary considerably, but the same premise holds for each one: apart from its mercantile nature and political, and even symbolic, function, a common currency serves as a marker of individual mobility in European space.

\subsection{Connecting the movements of coins and people}

The data compiled in the ESDO surveys cannot be used to make direct deductions of the movements of people from the spatial diffusion of euro coins in France. But we can use those data to observe the resulting spatial markers in varying time steps. These markers are not collected at the moment of the movement in space, as with a GPS for example, and do not consist of a series of staging points completed by each coin. It is after the event, on the basis of a series of photographs of the spatial distribution of the coins at regular time intervals, that we can see the redundancy of the flow of coins diffused from one place of reference to a given location, and that we can postulate on the markers of mobility.

These markers of the circulation of euro coins can be interpreted as the markers of the circulation of people, since the movement of the coins mainly results from the movement of individuals and a succession of transactions (Grasland and Guérin-Pace, 2004). Coins are transferred from one individual to another either directly or through a commercial pool. And while these pools fuel the random mixing of the coins, it is the individuals who are the main drivers of the process through their daily movements and purchases.

\footnotetext{
${ }^{3}$ A Lévy flight, named after the French mathematician Paul Lévy, is a special class of randomwalk in which the step-lengths are not constant but have a probability distribution that is heavy-tailed due to frequent long-term movements.
} 
These transactions are made as part of a chain. A coin may circulate within the same country for a certain period of time and then cross a border as part of a business trip to a large city and henceforth be exchanged only in the new country. But coins may also circulate as part of incessant to-and-fro movements between two countries in the daily border crossings of the local population.

While the image on the obverse side of the coin tells us where it was issued, it tells us nothing about the precise location where it was brought into circulation, the paths it has taken, the miles covered or the number of intermediary carriers through to the observation point. As such, we cannot know precisely how many times it has entered or left a country; we can only estimate the resultant of the movements through the presence of coins of different origins in a given territory.

Just as the transmission of family names (Darlu and Ruffié, 1992) and specific genes (Cavalli-Sferza and Edwards, 1967) from one world region to another sheds light on migratory movements, the circulation of euro coins reveals contacts between the residents ${ }^{4}$ of euro-zone countries. In the present study, we make the assumption that the higher the number of people circulating from one territory to another located abroad, the higher the number of coins carried between the two territories in question - and the more visible the markers of international mobility.

Our aim in this article will be to distinguish the factors explaining the high or low number of foreign coins in different parts of France and to determine the proportion of those coins by reconstructing a series of econometric models ${ }^{5}$. We will seek to go beyond the basic observation of the gravitational flows of coins into and out of the countries bordering France, which explain differences in the number of foreign coins in line with their origin and their diffusion after crossing the border (Grasland et al., 2012).

\subsection{Towards a perfect mix?}

The diffusion of foreign euro coins follows what Cliff (1981) refers to as a "relocation diffusion" process. International mobility leads to a continuous rise in the number of foreign coins in a country, which itself leads to an increase in the number of international coins leaving the country. The long-term upshot of the process would be a "perfect mix" of coins regardless of origin, in other words an equal distribution of coins, proportionate to their respective weight in all the coins circulating in the euro zone. The identity of the issuing country becomes increasingly blurred as the mixing process continues, erasing

4 Resident here means any person having lived temporarily or permanently in a euro-zone country during the period of the study.

5 Multivariate binomial logistic regression models were implemented to estimate the probability of a coin being issued abroad or not (binary dependent variable) in line with a series of predictive variables (in continuous or discrete form), the effect of each one being measured independently of the others. The main idea of this approach is to inform which set of explanatory variables better explains the variation in the prevalence of foreign coins by comparing the obtained likelihoods as well as the significance and value of the coefficients. 
the markers of mobility. But contrary to the optimistic assumptions of physicists on the speed of the process, that mix is still far from being reached (Le Texier and Caruso, 2016), the process being slowed in particular by the regular minting of new coins by each country and new euro-zone members (Seitz et al., 2012).

\subsection{Uneven diffusion of coins by face value}

Numismatic historians have shown that the diffusion of coins and notes differs according to their face value. This was for instance already the case in the Roman era, when bronze coins were used locally to buy bread, wheat, wood and pay craftspeople, whereas gold and silver coins, reserved for the elite, circulated in step with the movements of the representatives of power, major merchants and armies (Bursche, 2002).

The same would appear to be true in the euro zone, whose inhabitants use different coins for different purchases and adopt different payment strategies. Generally speaking, bronze coins bearing the lowest face values are used less frequently than the other coins, to the extent that some countries have already abandoned one- and two-cent coins (including Finland and the Netherlands) and rounded prices up to five cents. One reason for this is that users find the bronze coins hard to tell apart, so they tend not to use them at the moment of payment (Nuno et al., 2005; Le Texier, 2014). As was the case in the past, these differences impact the international circulation of coins according to their face value. The higher the value of the coin, the higher the probability of diffusion, thereby increasing the chance that the coin will be seen in a foreign country (Figure 1). Also, as the date of the introduction of the euro recedes, the proportion of foreign euro coins in France grows (Figure 1), introducing a further bias in the estimation of contacts on the basis of the diffusion of euro coins.

These impacts, which can be qualified as mechanical, can be easily accounted for in modelling. We first sought to precisely measure their influence on the probability that a coin observed at a given time was minted abroad or not (Table 2, Model I). We observed a regular progression of the parameters with the observation date and value of the coins.

\section{Coin carriers and high-mobility individuals}

Coins are distributed over time and across the euro zone in line with human mobility and through monetary transactions. The spatio-temporal propagation of foreign euro coins is largely driven by mobile individuals. That said, an individual with relatively low mobility but living in an internationalized territory may also be behind the diffusion of foreign coins. But we can make the assumption that, as in the case of epidemiological processes ${ }^{6}$,

6 But unlike contagion models, once the coin is transmitted to a new person, the transmission probability of the giver is lost or - if they have other coins - reduced. 
the probability of contact with euro coins issued abroad is related to the individual characteristics of the carrier.

\subsection{The frequency of international interactions depends on the social group}

The probability of an individual having foreign coins in his/her purse depends on the structure of their social networks and mobility locations. A person may come into contact with foreign euro coins while travelling abroad or because they know people or frequent places in the rest of Europe. While it is impossible to distinguish between these two situations at individual level, we can observe whether some social groups tend to have more or less contact with foreign coins than others.

International mobility is socially differentiated, with some groups travelling very little and in unvarying and limited spaces. According to Castells (1996), the first level of the "space of global flows" is characterized by the spatial organization of dominant elites enjoying economic or decision-making power. International business travellers stand out from the rest of the working population through the regularity of their professional trips abroad, with up to several per month (Chevrier and Sauvage, 2006). In addition, the trip frequency and destinations of business travellers vary in line with their professional status, income and gender (Aguilera, 2008; Mallett, 2001). Individual and family characteristics also play a role in tourist travel, in terms of both constraints and preferences (Urry, 2012).

Moreover, "transnational elites" have specific practices, frequent certain types of places or city districts, and ultimately interact with only a few categories of the local population (Beaverstock, 2002). Consequently, the odds of the inhabitants of a given territory "picking up" a foreign euro coin will differ in line with their social category and daily habits.

\subsection{Social inequalities in contact with foreign euro coins}

In light of the observations above, in addition to mechanical effects we introduced parameters on the individual characteristics of the respondents and analysed their impact on the possession of foreign euro coins. The assumptions are confirmed by the study of the circulation of euro coins. The gender, age and profession of the coin carrier have a considerable impact on the probability of their carrying a coin minted in another country (Table 2, Model 2).

We also observe that, all things being equal in terms of the other variables, men are more likely than women and young people more likely than older people to be in possession of a foreign coin. Socio-economic characteristics also play a role on the probability of having a foreign coin in one's possession. Farmers are far less likely to come into contact with foreign euro coins than people in other socio-professional categories, apart from manual workers, with whom no significant difference was observed. Self-employed 
tradespeople and shopkeepers are the most likely to have foreign coins in their possession. These probabilities shift according to where the coin carrier lives. For example, a retired person living near the German border is more likely to come into contact with a foreign coin than a retiree in a small town in Brittany, even though the two individuals have the same daily consumption habits and similarly limited mobility. In the next part of this article we will seek to define the most internationalized territories from the viewpoint of the international circulation of coins.

\section{Toward a geography of the internationalization of territories}

Our hypothesis here is that some euro-zone territories are more interconnected than others through the degree and nature of their mobility. On the basis of the findings of Grasland et al. (2005) and Le Texier (2014), we posit the existence of several temporal scales affecting international mobility in Europe that, combined with the distances travelled and the characteristics of the territories, can be used to make a connection between the circulation of euro coins and that of people.

\subsection{The incessant movement of coins in cross-border areas}

The daily to-ing and fro-ing across national borders results in a strong mix of coins over very short spatial distances, as part of a Brownian-type movement. As such, we assume that within these border areas, numerous coins cross and re-cross the border every day, owing to the cross-border movements of workers and consumers motivated by differences in salaries and prices.

More specifically, spatial diffusion models are based on the hypothesis that the probability of contact between individuals - and thus of the propagation of a phenomenon from one place to another - is stronger between places that are close together, as distance hinders the intensity of travel and, consequently, the frequency of contact (Tobler 1970). Apart from the continuous effect of distance, the processes of spatial diffusion also show the presence of discontinuities, markers of preferred relations or barrier effects (Nijkamp et al., 1990). This neighbourhood effect, assuming it is limited to a restricted perimeter or one contiguous with a border, could be more simply resumed by a binary variable providing information on whether the town of residence of a respondent belongs to a border area or not (Ratzel, 1897) ${ }^{7}$.

\subsection{Regular flows of coins to large cities}

\footnotetext{
${ }^{7}$ The authors have previously tested different definitions of the distance effect, including linear, power and exponential gradual attenuation effects. The one proposed in this article showed the higher explanatory power.
} 
For its part, international mobility occurs at a slower pace, leading to fewer border crossing for coins but carrying them across greater distances, thereby diminishing the probability of their returning to the country of issue. This would enhance the mixing process and result in peak numbers of foreign coins in specific places, namely large European cities.

A number of studies, notably in the 1990s, have sought to characterize the degree of internationality of European cities (see for example Bonneville, 1994; Cattan, 1995; Pumain and Saint-Julien, 1996; and more recently, Cicille and Rozenblat, 2003). The attractiveness criteria used in the most recent studies are primarily based on cultural and academic influence, value-creating economic sectors such as finance, research, the presence of large business groups, and industry fairs and shows (Beaverstock et al., 2000). Another major criterion in this respect is the tourist appeal of large cities (Edwards et al., 2008). The human circulation resulting from these factors would suggest that these cities see a greater number of foreign coins.

\subsection{Foreign coins' flows higher in tourist seasons}

International tourist flows are highly seasonable (Baum and Hagen, 1999), with foreign coins arriving in a given territory in waves. This seasonal aspect being consistent from one year to the next (Kulendran and Wong, 2005; Croce and Wöber, 2009), we can measure the effect of tourism on the international movement of euro coins by distinguishing surveys carried out in the summer or at the end of the year from surveys administered in other periods.

Seasonal or annual mobility, then, plays a particular role in the process of transnational mobility, since it involves a considerable number of movements in very short periods of time and over varying distances. This type of mobility may not move a great number of coins when compared with the year as a whole, but it does constitute a significant mass of currency circulating towards tourist areas ${ }^{8}$.

\subsection{Spatial and seasonal factors in the mobility of foreign coins in France}

To the mechanical effects and the characteristics of carriers introduced in the two previous models, we have added in a final model the characteristics specific to a territory, as described above. We indicated the region in which the coin was observed (ZEAT), the

\footnotetext{
${ }^{8}$ It is worth noting that none of the touristic variables (provided online by the French national institute for statistics) introduced in the model during the testing phases - such as the number of foreign tourists visiting a region or the number of beds available in the tourist industry - had a significant impact on the internationalization of the money bags. The authors believe that this is due to a mismatch between the territorial scale at which these data are provided and the spatial resolution of the ESDO data.
} 
size of the municipality, its relative closeness to a national border ${ }^{9}$ and the seasonality of the survey to take account of the varying attractiveness of territories depending on the time of year (Table 2, Model III).

It can first be noted that the introduction of territorial and seasonal factors reduces the extent of mechanical and social effects, diminishing the significance of differences in professional categories and age while increasing differences in the face value of the coins or the survey year. It would appear that some of these effects interact with each other. As we assumed, it is after the summer and, to a lesser extent, after the end-of-year holidays that the number of foreign coins in France is at its highest. Adding the seasonal variable also helps us to more finely appraise temporal aspects.

Secondly, some social and demographic inequalities regarding the probability of contact with foreign euro coins can be superimposed onto territorial inequalities, since a number of these effects become harder to tell apart (this is true for professional category, excluding self-employed tradespeople and shopkeepers) or the difference between them shrinks once territorial effects are introduced in the model (age). The prevalence of foreign coins changes according to French regions. The probability of contact with a foreign coin is highest in Eastern France, on the borders with Germany and Luxembourg, and along the Mediterranean coast. Foreign coins are at their rarest in regions most distant from a border with a euro-zone country.

The effect of proximity between the region where a euro coin is observed and a foreign euro-issuing country is, for border regions, combined with the effect of belonging to a border-contiguous territory, since the coins observed within $50 \mathrm{~km}$ of a border are more likely to be foreign than in the rest of the territory, all other effects being taken into account.

The international appeal of the Parisian agglomeration is reflected in a higher proportion of foreign euro coins than observed elsewhere in France. Interestingly, the urban hierarchy criterion does not have a linear impact on the probability of observing a foreign euro. The difference between Paris and rural municipalities (of under 2,000 inhabitants) is lower than between the capital and towns of over 100,000 inhabitants. That counterintuitive result calls for a more precise observation of the territorial nature of the distribution of foreign coins across France. Finally, in our last model we distinguished foreign coins according to the distance of their country of minting. It was found that this distinction did not change the structural explanatory factors behind the overall presence of foreign coins in France.

\section{Discussion and perspectives}

9 Closeness here is considered as within $50 \mathrm{~km}$ of a border with a euro-zone country. This choice is the result of a trial and error approach, during which the effects of several distance scopes have been tested. 
Once the factors behind the international circulation of coins were updated, it is possible to observe the spatial nature of the diffusion of euro coins so as to identify the most international places in France. Based on the estimates provided by the model integrating commonplace, temporal, social and territorial effects (model III), we estimated the degree of European contact for each point of the French territory, which we then compared with the observed values. The mapping shown in Figure 2 serves to identify the places towards and from which contact occurs the most frequently between European residents.

Mapping the presence of foreign euro coins (Figure 2, map 1) shows an uneven diffusion of foreign euro coins in France. We observe, on one hand, the peripheries of the country as spaces with high potential for European integration (cross-border relations) and, on the other hand, the country's main metropolitan areas, such as Paris, Lyons, Marseille-Nice and Lille. ${ }^{10}$

Mapping of the residuals of the model (Figure 2, map 2) also reveals some interesting results. It sheds light on the varying degrees of porosity of border areas, with foreign coins more numerous than predicted by the model around the Lille metropolitan area, close to the Luxembourg border, and at the feet of the Southern mountain regions, as these last are the necessary crossing points for Spain and Italy.

Some large French urban areas also turn out to be more "internationalized" than their geographical position and population size would lead one to believe. This appears to reflect the city's economic specialization (advanced services, international head offices and so on), which is the case with Lyons and Nantes, or its status as a university city, true of Rennes for example. A high number of foreign coins in a given location also denotes attractive tourist destinations, including the Mediterranean and Southern Atlantic coasts, Poitou and Northern Brittany (probably owing to the proximity of Mont-Saint-Michel, one of the most visited sites in France).

These are just narrow hypotheses about the specific attractiveness of the places benefiting from the highest international circulation of coins in France. Undeniably, further researches have to be undertaken in order to light on the existence and causes of preferential attractiveness of cities at the European level and should be the subject of a dedicated article.

Indeed, the primary objectives of this paper were to test the empirical relevance of using the circulation of euro coins to track the paths of individual mobility in the absence of data and to provide a general view of the spatio-temporal scales, motives and actors of cross-border mobility in Europe, thereby completing the existing sectoral approaches.

10 It should however be noted that the appearance of a high probability "spot" in the Southern Paris region is in reality an artefact resulting from the low number of observations in this area and from a high number of foreign euro coins nearby, linked to the Paris region. 
For the same reason, this research only investigates the dichotomy of French vs. foreign coins, despite the clear expectation that coins from different countries will be present in different quantities in different places. In a next study, we plan to segment our model into as many geographical origins as there are countries in the euro zone to reveal the territorial subsystems with the strongest interactions. Finally, our study focuses on one particular dimension of the Europeanisation of territories and social groups in France: the movements of people. Obviously one could obtain a very different picture while looking at the flows of goods or financial flows.

\section{Conclusion}

On the basis of our analysis, we conclude that the diffusion of foreign euro coins in France can be used to outline spaces of European mobility and, in particular, to show the uneven porosity of borders to transnational flows. It can also help to identify the metropolitan areas that are the most integrated in the system of European cities in terms of movements of people and to measure the markers left behind by the frequenting of tourist areas.

In the end, from monetary finds dating from Antiquity through to the introduction of the euro, currencies have always provided a relevant track of contact between people and the numerous paths connecting them. 


\section{BIBLIOGRAPHY}

AGUILERAA. 2008. Business travel and mobile workers. Transportation Research Part A 42: 1109-1116.

BAUM T, HAGEN L. 1999. Responses to seasonality: the Experiences of peripheral destinations. International Journal of Tourism Research 1: 299-312.

BEAVERSTOCK JV, SMITH RG, TAYLOR P J. 2000. World-City Network: A New Metageography? Annals of the Association of American Geographers 90: 123-134.

BEAVERSTOCK JV. 2002. Transnational elites in global cities: British expatriates in Singapore's financial district. Geoforum 33: 525-538.

BERGMAN T, LAURI A, RUHALA A, RYDMAN W. 2002. Euro coin diffusion. In Proceedings of the EPS-12: Trends in Physics. European Physical Society: Budapest.

BERROIR S, GRASLAND C, GUÉRIN-PACE F, HAMEZ G. 2005. La diffusion spatiale des pièces euro en Belgique et en France. Revue belge de Géographie (Belgeo) 4 : 345358.

BROCKMANN D, HUFNAGEL L. 2007. The Scaling law of human travel - A message from George. In Complex Population Dynamics. Nonlinear Modeling in Ecology, Epidemiology and Genetics, Blasius B, Kurths J, Stone L (eds.); World Scientific Publishing: Singapore; 109-127.

BROCKMANN D, THEIS F. 2008. Money circulation, trackable items, and the emergence of universal human mobility patterns. IEEE Pervasive Computing 7: 28-35.

BONNEVILLE M. 1994. Internationalization of non-capital cities in Europe: aspects, processes and prospects. European Planning Studies 2: 267-285.

BURSCHE A. 2002. Circulation of Roman Coinage in Northern Europe in Late Antiquity. Histoire \& mesure 17: 121-141.

CASTELLS M. 1996. The Rise of the Network Society. Blackwell: Oxford.

CATTAN N. 1995. Attractivity and internationalisation of major European cities: the example of air traffic. Urban Studies 32: 303-312.

CAVALLI-SFERZA LL, EDWARDS W. 1967. Phylogenetic analysis. Models and estimation procedures. American Journal of Human Genetics 19: 233-257.

CHEVRIER S, SAUVAGE A. 2006. Plein Cadre. Les cadres internationaux à l'épreuve du déplacement. In La ville aux limites de la mobilité, Bonnet M, Aubertel P (eds.); Presses Universitaires de France: Paris; 175-182. 
CICILLE P, ROZENBLAT C. 2003. Les Villes Européennes, Analyse Comparative. DATAR: Paris.

CLIFF AD. 1981. Spatial Diffusion: an Historical Geography of Epidemics in an Island Community. Cambridge University Press: Cambridge.

CROCE V, WÖBER KW. 2009. Seasonality in City Tourism: Concepts and Measurements. In Analysing International City Tourism, Mazanec JA, Wöber KW (eds.); Springer: Vienna; 59-80.

DARLU P, RUFFIÉ J. 1992. L'immigration dans les départements français étudiée par la méthode des patronymes. Population 47: 719-734.

EDWARDS D, GRIFFIN T, HAYLLAR B. 2008. Urban tourism research. Developing an agenda. Annals of Tourism Research 35: 1032-1052.

GRASLAND C, GUÉRIN-PACE F, TOSTAIN A. 2002. The circulation of euros as a reflection on people mobility. Population and Societes 384 : 1-4.

GRASLAND C, GUÉRIN-PACE F. 2004. Mobilité européenne, tourisme et diffusion des pièces euros étrangères en France. Revue d'Economie Régionale et Urbaine 5 : 793-822.

GRASLAND C, GUÉRIN-PACE F, TERRIER C. 2005. La diffusion spatiale, sociale et temporelle des pièces euros étrangères : un problème complexe. Actes des journées de Méthodologie Statistique. French Institute of Statistics: Paris.

GRASLAND C, GUÉRIN-PACE F, LE TEXIER M, GARNIER B. 2012. Diffusion of foreign euro coins in France, 2002-2012. Population and Societies 488: 1-4.

HUDSON R. 2004. Thinking Through the geographies of the new Europe in the new millennium: Dialectics of circuits, flows and spaces. European Urban and Regional Studies 11: 99-102.

KULENDRAN N, WONG KF. 2005. Modeling seasonality in tourism forecasting. Journal of Travel Research 44: 163-170.

LE TEXIER M, CARUSO G. 2016. Aggregate and disaggregate dynamic spatial interaction approaches to modelling coins diffusion. In Innovations in Urban and Regional Systems Research - Contributions from GIS\&T, Spatial Analysis and Location Modeling, Thill JC (ed.), Springer's Advances in Spatial Science Series: Berlin.

LE TEXIER M. 2014. Les circulations internationales au XXIeme siècle. De l'étude des répartitions monétaires á la modélisation d'un système complexe. $\mathrm{PhD}$ Thesis, University Paris Diderot and University of Luxembourg.

MALLETT WJ. 2001. Long-distance travel by low-income households. Transportation Research E-circular. Transportation research board: Washington D.C; 169-177. 
NIJKAMP P, RIETVELD P, SALOMON I. 1990. Barriers in spatial interactions and communications. A conceptual exploration. Annals of Regional Science 24: 237-252.

NUNO J, GRASLAND C, BLASCO F, GUÉRIN-PACE F, OLARREA J. 2005. How many coins are you carrying in your pocket ? Physica A 354: 432-436.

PUMAIN D, SAINT-JULIEN T. 1996. Urban Networks in Europe. John Libbey: Paris.

RATZEL F. 1897. Politische Geographie. R. Oldenbourg Verlag: München.

SEITZ F, STOYAN D, TÖDTER KH. 2009. Coin migration within the euro area. Deutsch Bundesbank Discussion Paper Series 1 : Economic Studies 27: 1-32.

SEITZ F, STOYAN D, TÖDTER KH. 2012. Coin migration and seigniorage within the Euro area. Jahrbücher für Nationalökonomie und Statistik 232: 84-92.

SOHN C. 2009. La diffusion des euros au Luxembourg, reflet de la mobilité des hommes. Vivre au Luxembourg 51: 1-2.

STOYAN D. 2002. Statistical analyses of Euro coin mixing. Mathematical Spectrum 35: $50-55$.

TOBLER W. 1970. A computer movie simulating urban growth in the Detroit region. Economic Geography 46: 234-240.

URRY J. 2012. Social networks, mobile lives and social inequalities. Journal of Transport Geography 21: 24-30. 
Box 1: ESDO survey methodology.

Each of the ESDO surveys in France (apart from the March 2002 survey, with 1,000 respondents) was carried out with a sample of 2,000 individuals aged 18 and over and representative of the French population. The 1990 census data, updated by the Employment Survey of 1999, were used to establish the survey plan. The theoretical representativeness was built on the basis of strata cross-referencing ZEATs and the size of towns (less than 2,000 inhabitants, between 2,000 and 20,000, between 20,000 and 100,000 , over 100,000, and the Paris agglomeration). In urban areas, the interviews were split between the central municipality of the agglomeration and peripheral municipalities in proportion to their population size. The questions on the euro coins were asked at the end of the questionnaire. Interviewers asked the respondents to count with them the coins in their purses and identify their geographical origin (issuing country) and value. To do so, they used a board featuring images of all French and foreign euro coins, grouped by value and geographical origin. Together, the interviewers and interviewees successively placed each coin on the corresponding image on the board. The interviewer then noted all the values and origins in a table. 
Table 1: Overview of ESDO surveys.

\begin{tabular}{|c|c|c|c|c|}
\hline Survey date & $\begin{array}{c}\text { Number } \\
\text { of re- } \\
\text { spondents }\end{array}$ & $\begin{array}{c}\text { Number of } \\
\text { purses } \\
\text { Surveyed }\end{array}$ & $\begin{array}{c}\text { Number of } \\
\text { coins ob- } \\
\text { served }\end{array}$ & $\begin{array}{c}\text { Proportion } \\
\text { of foreign } \\
\text { coins }\end{array}$ \\
\hline June 2002 & 2,012 & 1,470 & 20,557 & 6.01 \\
September 2002 & 2,057 & 1,415 & 19,800 & 9.24 \\
January 2003 & 2,042 & 1,453 & 18,148 & 11.19 \\
June 2003 & 1,998 & 1,278 & 18,001 & 10.70 \\
September 2003 & 1,978 & 1,394 & 17,686 & 13.94 \\
December 2003 & 2,013 & 1,531 & 20,436 & 13.86 \\
June 2004 & 1,999 & 1,418 & 18,347 & 17.15 \\
September 2004 & 1,988 & 1,410 & 18,254 & 19.58 \\
December 2004 & 2,012 & 1,657 & 21,781 & 19.02 \\
June 2005 & 2,003 & 1,386 & 18,118 & 20.18 \\
December 2005 & 1,989 & 1,574 & 19,869 & 23.66 \\
June 2006 & 1,989 & 1,308 & 15,967 & 26.37 \\
January 2007 & 2,000 & 1,450 & 18,636 & 26.50 \\
October 2008 & 2,010 & 1,530 & 18,239 & 29.71 \\
December 2011 & 1,096 & 1,395 & 17,198 & 34.12 \\
\hline Total & 29,186 & 21,669 & 281,037 & \\
\hline
\end{tabular}


Table 2: Factors in the international movement of euro coins in France

\begin{tabular}{|c|c|c|c|c|}
\hline & & $\begin{array}{l}\text { Model I: } \\
\text { Mechanical } \\
\text { effects } \\
\text { Odds Ratio }\end{array}$ & $\begin{array}{l}\text { Model II: } \\
\text { Mechanical } \\
\text { and social ef- } \\
\text { fects } \\
\text { Odds Ratio }\end{array}$ & $\begin{array}{l}\text { Model III: } \\
\text { Mechani- } \\
\text { cal, social } \\
\text { and terri- } \\
\text { torial ef- } \\
\text { fects } \\
\text { Odds Ratio }\end{array}$ \\
\hline Year & $\begin{array}{l}2002 \\
2003 \\
2004 \\
2005 \\
2006 \\
2007 \\
2008 \\
2011 \\
\end{array}$ & $\begin{array}{l}\text { Ref. } \\
1.670^{* * *} \\
2.490^{* * *} \\
3.073 * * * \\
4.144 * * * \\
4.639 * * * \\
5.560 * * * \\
6.838 * * *\end{array}$ & $\begin{array}{l}\text { Ref. } \\
1.670^{* * *} \\
2.495^{* * *} \\
3.075^{* * *} \\
4.145^{* * *} \\
4.649 * * * \\
5.568^{* * *} \\
6.885^{* * *}\end{array}$ & $\begin{array}{l}\text { Ref. } \\
1.689 * * * \\
2.667 * * * \\
3.753 * * * \\
4.964 * * * \\
5.253 * * * \\
4.788 * * * \\
9.030 * * *\end{array}$ \\
\hline Value & $\begin{array}{l}1 \text { cent } \\
2 \text { cent } \\
5 \text { cent } \\
10 \text { cent } \\
20 \text { cent } \\
50 \text { cent } \\
1 \text { euro } \\
2 \text { euros }\end{array}$ & $\begin{array}{l}0.325^{* * *} \\
0.372^{* * *} \\
0.674 * * * \\
\text { Ref. } \\
1.388^{* * *} \\
1.997^{* * *} \\
1.819^{* * *} \\
1.779^{* * * *}\end{array}$ & $\begin{array}{l}0.326^{* * *} \\
0.374^{* * *} \\
0.676^{* * * *} \\
\text { Ref. } \\
1.390^{* * *} \\
1.999^{* * *} \\
1.819^{* * *} \\
1.781^{* * * *}\end{array}$ & $\begin{array}{l}0.324 * * * \\
0.376 * * * \\
0.677 * * * \\
\text { Ref. } \\
1.402 * * * \\
2.001 * * * \\
1.839 * * * \\
1.802 * * *\end{array}$ \\
\hline Gender & $\begin{array}{l}\text { Women } \\
\text { Men }\end{array}$ & & $\begin{array}{l}\text { Ref. } \\
1.082 * * *\end{array}$ & $\begin{array}{l}\text { Ref. } \\
1.084 * * *\end{array}$ \\
\hline Age & $\begin{array}{l}>=65 \\
50-64 \\
35-49 \\
25-34 \\
18-24 \\
\end{array}$ & & $\begin{array}{l}\text { Ref. } \\
1.112 * * * \\
1.124 * * * \\
1.163 * * * \\
1.170 * * *\end{array}$ & $\begin{array}{l}\text { Ref. } \\
1.082 * * * \\
1.086 * * * \\
1.129 * * * \\
1.142^{* * * *} \\
\end{array}$ \\
\hline Profession & $\begin{array}{l}\text { Farmer } \\
\text { Craftsperson, shop- } \\
\text { keeper } \\
\text { Worker } \\
\text { Service employee } \\
\text { Executive } \\
\text { Inactive }\end{array}$ & & $\begin{array}{l}\text { Ref. } \\
1.289^{* * *} \\
\text { n.s. } \\
1.176^{* *} \\
1.203^{* *} \\
1.203^{* *}\end{array}$ & $\begin{array}{l}\text { Ref. } \\
1.191^{* * *} \\
\text { n.s. } \\
\text { n.s. } \\
\text { n.s. } \\
\text { n.s. }\end{array}$ \\
\hline Border area & $\begin{array}{l}\text { No } \\
\text { Yes }\end{array}$ & & & $\begin{array}{l}\text { Ref. } \\
1.911 * * *\end{array}$ \\
\hline NUTS1 & $\begin{array}{l}\text { Ile-de-France } \\
\text { Bassin-Parisien Est } \\
\text { Bassin-Parisien Ouest } \\
\text { Est } \\
\text { Méditerrannée } \\
\text { Nord } \\
\text { Ouest } \\
\text { Sud-Est } \\
\text { Sud-Ouest } \\
\end{array}$ & & & $\begin{array}{l}\text { Ref. } \\
\text { n.s. } \\
0.863^{* * *} \\
1.451^{* * *} \\
1.455^{* * *} \\
1.101^{*} \\
0.801^{* * *} \\
1.088^{*} \\
\text { n.s. } \\
\end{array}$ \\
\hline $\begin{array}{l}\text { Agglomeration } \\
\text { population } \\
\text { (in thousands } \\
\text { of inhabitants) }\end{array}$ & $\begin{array}{l}\text { Parisian agglo. } \\
\geq 100 \\
20 \text { to } 100 \\
2 \text { to } 20 \\
\leq 2\end{array}$ & & & $\begin{array}{l}\text { Ref. } \\
0.729 * * * \\
0.886^{* *} \\
0.793 * * * \\
0.818^{* * *}\end{array}$ \\
\hline Season & $\begin{array}{l}\text { January } \\
\text { June } \\
\text { September/October } \\
\text { December }\end{array}$ & & & $\begin{array}{l}1.126 * * * \\
1.129 * * * \\
1.537 * * * \\
\text { Ref. }\end{array}$ \\
\hline
\end{tabular}

* Key: the modality modelled here is the foreign nature (95,890 coins) or domestic nature (185,147 coins) of a coin, all periods combined. The odds ratios reflect the varying probability that a coin has been minted abroad according to the value or modality of the explanatory factor (for example, a value of 2 euros) rather than the reference modality (10 cents). That probability is significantly higher (respectively lower) than for the reference modality when the odds ratio is significantly higher (respectively lower) than 1, and is interpreted everything else being equal. Coefficients marked with three stars are significant from a threshold of $1 \%$, those with two stars from a threshold of $5 \%$ and those with one star from a threshold of 10\%. Above this last threshold, the value is considered as not significant (n.s.).

Scope: 281,037 coins observed in France between June 2002 and December 2011. 
Figure 1: Proportion of foreign euro coins in France by face value (2002-2011). Source: ESDO.

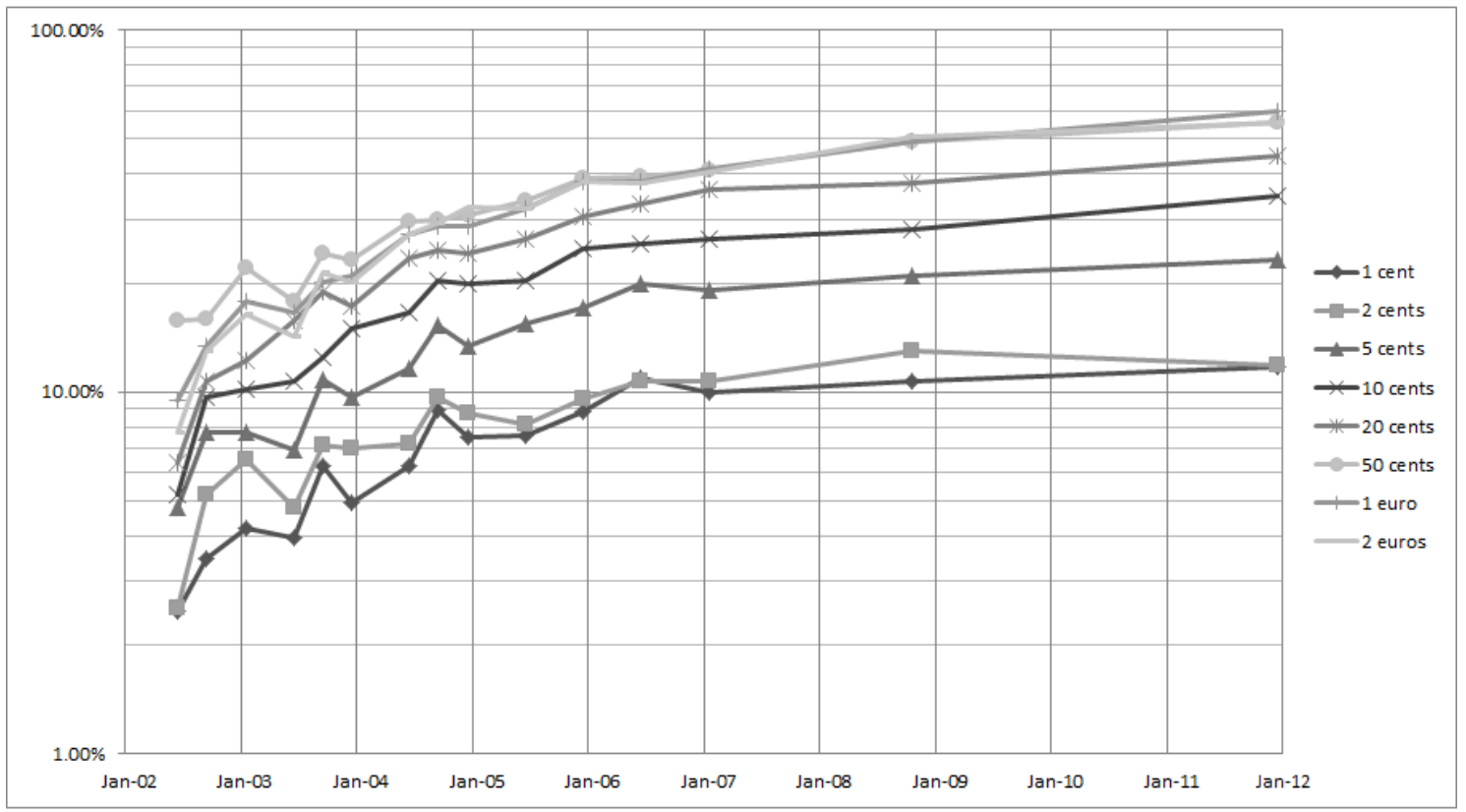

Note: the points plotted on the graph indicate the surveys date 
Figure 2: Estimated and observed circulation of foreign euro coins in France (20022011). Source: ESDO.

Map 1 : Estimates of foreign euro
coins provided by model III
Map 2 : Deviations from model III (the
scaling uses the mean and the standard
deviation)

